Article

\title{
Changes in Local People's Perceptions of the Sumava National Park in the Czech Republic over a Ten Year Period (1998-2008)
}

Tomas Gorner $^{1,2, *}$, Klara Najmanova ${ }^{1}$ and Martin Cihar ${ }^{1}$

1 Institute for Environmental Studies, Faculty of Science, Charles University, Benatska Street, Prague, 12801, Czech Republic; E-Mail: ciharm@gmail.com (M.C.)

2 Agency for Nature Conservation and Landscape Protection of the Czech Republic, Kaplanova Street, Prague, 14800, Czech Republic

* Author to whom correspondence should be addressed; E-Mail: tomas.gorner@nature.cz; Tel.: +420-283-069-237.

Received: 2 April 2012; in revised form: 4 May 2012 / Accepted: 13 June 2012 /

Published: 19 June 2012

Abstract: The Sumava National Park (NP), the largest protected area of its kind in Central Europe, is as interesting as it is problematic (historical development, conflicts between regional development and landscape protection). In order to evaluate the success of the Park's policies, local park inhabitants' attitudes were assessed over a ten-year period. Two surveys $(\mathrm{N}=181$ and $\mathrm{N}=200)$ were conducted in August, 1998 and 2008. The questionnaires consisted of 43 queries from three thematic areas; (a) socio-demographic data, (b) environment and nature conservation, and (c) sustainable tourism and local development. The comparison of the results 1998 with 2008 showed that the Park inhabitants perceived living in the Park as improving and the scheme for nature conservation as either "optimal" or "more strict". The surveys also showed the loss of job opportunities as the most prevalent local concern. In a cluster analysis based on perceptions of (a) the Park, (b) the environment and (c) Park Administration, subjects were divided into four opinion groups ranging from "optimists" to "grumblers". The most "positive (optimistic)" group saw little connection between the Park's existence and job losses, while the most "negative" group saw a strong connection in that regard.

Keywords: protected areas; resident's attitudes; sustainable management; social climate 


\section{Introduction}

The designation of protected areas (PAs) is currently the most widely adopted means of conserving natural ecosystems [1]. Whilst the conservation of nature is the primary concern in PAs, it is also recognized that meeting the needs and priorities of local residents is vital to the long-term survival of such areas. Planning and management of PAs should involve local communities and build upon their traditional knowledge and expertise. Whenever possible, local communities should benefit directly from the establishment and management of a protected area [2-7]. The existence of a protected area may have a positive effect on employment and economic development, which are very often critical issues among local people [8]. The nearby wilderness may enhance the attractiveness of the region as a place [9].

A lack of local participation in the designation procedure, and also in the decision-making process, results in conflicts with, and resistance to, the managing authority. Protected areas cannot productively co-exist with communities that are hostile to conservation management [10]. However, they can achieve significant social and economic objectives when placed in a proper context. The involvement of local people is more successful when park planning is participatory and when political and socio-economic reforms are underway [11]. Local residents are often in conflict with park authorities in cases where the park management is centralized and not participatory [2,12]. Use of economic incentives is usually more successful than authoritarian regulation when it comes to enlisting local support for conservation programs [13].

Substantial research on the attitudes of local residents towards protected areas has been conducted in various countries [14-19]. Negative attitudes are frequently associated with situations where the perceived costs to individuals and communities outweigh the perceived benefits [20-22]. One of the most frequently discussed factors influencing local people's acceptance of protected areas is place attachment (reviewed e.g., in [23]). For example, Walkera and Ryan [24] conclude that there is a strong positive correlation between rural residents' level of support for conservation planning and their level of attachment to the landscape. Bonaiuto et al. [25] state that subjects who are more involved in local economic activities show more negative attitudes toward natural protected areas (generally and specifically) and higher degrees of place attachment than subjects who are more involved in ecological and pro-environmental activities. In addition, social climate alone can adversely affect the effectiveness and sustainability of PA management [26,27].

In Central Europe, which has been relatively unstable economically and politically from the Second World War through the late 1990's, local opinion surveys regarding PAs have the potential to provide interesting and useful results. The present survey is part of a long-term project studying sustainable tourism and development in protected areas of the Czech Republic [28-31]. The original case study-based research has grown into a comprehensive system of indicators and monitoring program for the evaluation of long-term environmental, social and economic changes in the national parks and biosphere reserves of the Czech Republic. This comprehensive research was supported by a grant from the Ministry of Environment $\mathrm{VaV} \mathrm{SP} / 4 \mathrm{i} / 40 / 08$. The baseline of our research can be formulated into two main questions: Can a system of focused questions thematically mapping the views and opinions of local residents reflect shifts in their acceptance and attitudes towards the relatively recently established protected area? And, is it possible on the basis of our results to identify the shift in local 
acceptance and social climate of the local population in relatively unstable political and socio-economic conditions in the immediate vicinity of the former so-called Iron Curtain? The main goal of this paper is to find the answer to the second above-mentioned question. In our case this is neither an insignificant matter nor a singularity, but a very important existential problem of one of the largest transboundary national parks and biosphere reserves in Central and Eastern Europe, which is currently exposed to extreme external and internal development and local, regional and supra-regional political pressures.

\section{Study Area}

The Sumava National Park (NP) is the Czech Republic's largest national park and is located in the southwestern region, on the border with Germany. The Park's area of $681 \mathrm{~km}^{2}$ is surrounded by the Sumava Protected Landscape Area (approximately $1000 \mathrm{~km}^{2}$ ), which serves as the Park's buffer zone (Figure 1). The Sumava mountain range is one of the oldest in Europe. The climate ranges from mild humid to cold humid, with annual precipitation of $800-1600 \mathrm{~mm}$ and an annual temperature range of $6.5-3.5^{\circ} \mathrm{C}$. The NP's elevation is between $600-1378 \mathrm{~m}$ and consists of a woody mountain range with vast plateaus and a variety of landscape types. The dominant type of vegetation is coniferous forest, which has largely displaced the climax deciduous forest stands. At present, the forest vegetation can be compared to a large mosaic, ranging from greatly changed, non-native coniferous forest communities to nearly pristine virgin growth.

Figure 1. Map of the Sumava National Park and the Sumava Protected Landscape Area (Source: authors).

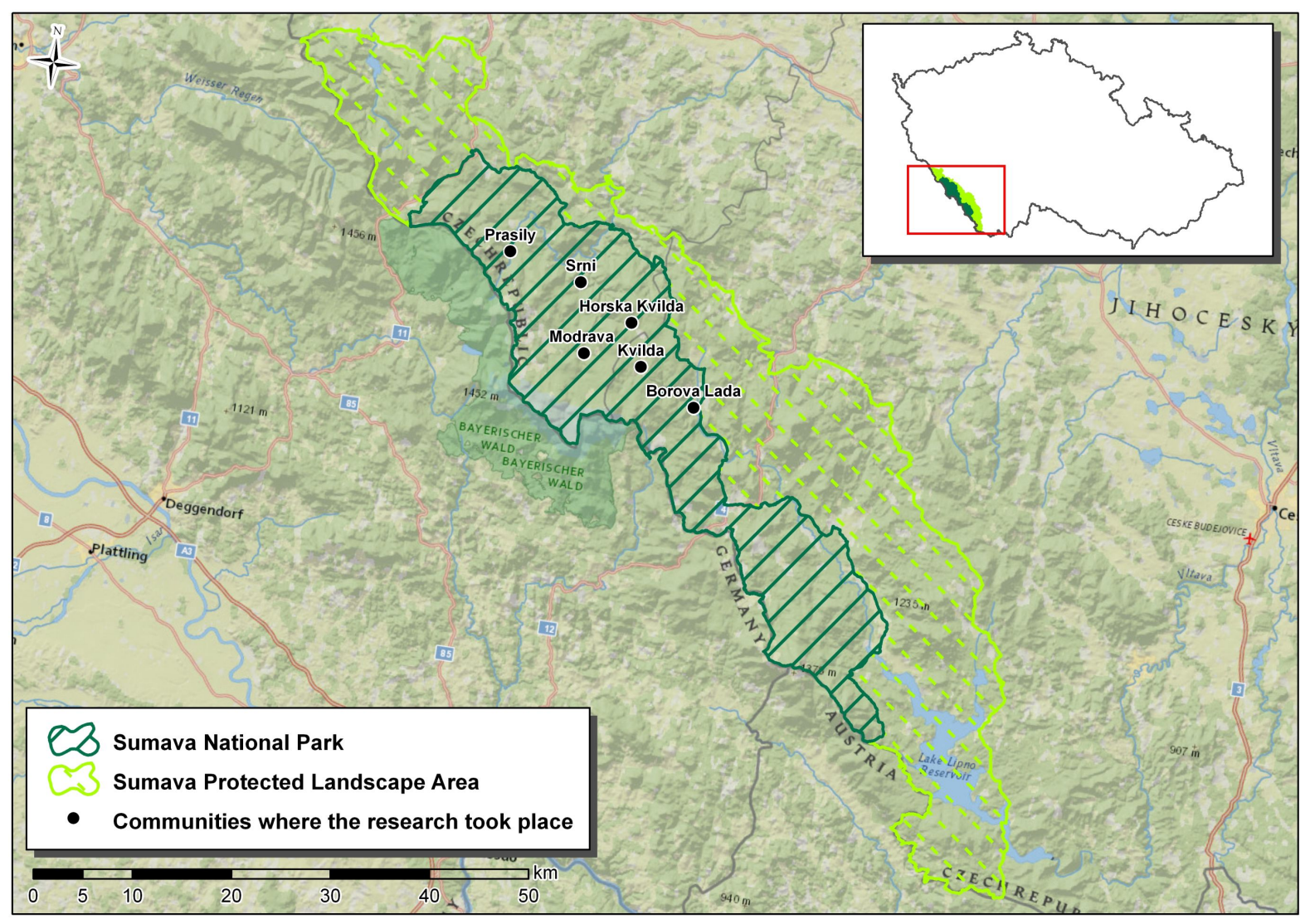


The Sumava NP contains a unique mountainous environment combined with many attractive cultural features. The first settlers of this region arrived during the Middle Ages. The wood-processing and glassmaking industries have a long tradition in this area. Later immigration into the area (17th-18th centuries) resulted in the further development of glass manufacture, intensive logging and livestock grazing. This period had a substantial, negative effect on the ecosystems. The exploitation of the forests led to an environmental imbalance further impaired by the replacement of original timber growth with non-native spruce species and excessive livestock grazing. As a result, there had been some disasters caused by high winds by the end of the 19th century. The problem of unsuitable wood growth with a high vulnerability to damage by emissions or pests, persists to the present day [32]. About 4000-5000 ha of declined spruce forests has been a consequence of these conditions and bark beetle attacks since 1995 [33].

In 1963, the area was designated by the Government of the Czech Republic as the Sumava Protected Landscape Area and in 1990 it was added to the UNESCO list of Biosphere Reserves. The Sumava National Park was established soon after the change in political regime in 1991. Together with the neighboring NP Bayerisher Wald (Bavarian Forest) in Germany it forms a transnational protected area. In fact, it currently represents one of the largest protected areas of its kind in Europe. Sumava is also an important part of the NATURA 2000, which is the EU network of natural sites designated by Member States under the Birds Directive (EEC/79/409 Directive) and under the Habitats Directive (EEC/92/43 Directive).

Before and after the Second World War, the region was affected by major political changes that considerably influenced the structure, number and social composition of the local population. The Sumava region was part of the Sudetenland, located on the Czechoslovakian border with Germany and Austria, which had a majority of ethnic German inhabitants. This area was incorporated into the Reich in 1938. A year later the Protectorate Bohemia and Moravia was proclaimed, followed by the occupation of the former Czechoslovakia. At the end of the Second World War, Germans were subjected to restrictive measures and by the end of 1946, some 1.7 million Germans had been resettled. The continuity of local settlement and also historical property rights was therefore interrupted [34]. Many villages were left empty and abandoned. The current inhabitants represent only $12 \%$ of the original population of 1930 [35]. After February 1948, radical Communists took power. The establishment of the 'Iron Curtain' between Western Europe and communist Eastern Europe, and the associated military training areas in Sumava, increased the isolation of the region. However, closing the area to the public after 1950 had a positive, recuperative effect on the local ecosystems.

In 1989, the Velvet Revolution introduced democratic changes in Czechoslovakia, opening borders and resulting in a completely new situation: Sumava became a popular tourist destination and went through intensive socio-economic development. This fast transition from a state-planned to a free market economy created tensions for sustainable development programs in the region [30].

As we can see, Sumava has evolved from a practically closed and marginal region behind barbed wire into an open and modern protected area in (since December 2007) Europe's border-free the Schengen zone. Since the early 1990s, there has been a continuous increase in visitor numbers to the NP. Nowadays, approximately 600,000 tourists visit Sumava NP every year and more than two million now visit the whole Sumava region [31]. At present, the Sumava region is facing both the positive effects and negative impacts of tourism. Sumava NP is faced with other problems. Since establishing 
the NP, there have been controversies in forest management, particularly whether the National Park mission should include felling trees affected by the bark beetle. This management approach has changed from interventionist (cutting and removal of invaded tress) to natural (self-regeneration of the forest) [36]. Probably the most acute weakness of the Sumava region is a set conflicts of interests related to different approaches to land-use from the points of view of landscape protection institutions and regional development strategies represented by municipalities and development agencies [37]. There is a need to define optimal, balanced land-use respecting the biological capacity of the landscape and evaluating the impacts of social and economical interference on the environment. Thus, the main goal for park management today is to balance these impacts in cooperation with the local inhabitants.

\section{Materials and Methods}

The main aim of the first research in 1998 was to collect basic data on local people's acceptance of the newly established Sumava National Park. Since there was hardly any participation by local stakeholders in the establishment procedure in 1991, negative attitudes towards the Park management authority were expected. In cooperation with the National Park Administration, the team of authors developed a questionnaire for face-to-face interviews. The questionnaire addressed various issues, such as basic demographic characteristics, local place relationship, acceptance of the NP, environmental and social matters, and the development of tourism. The pre-survey took place in spring 1998 and this was perhaps the first time that the residents of the Sumava National Park and Biosphere Reserve had had an opportunity to express their opinions and perceptions of management and policies in the area. Ten years later, the team decided to repeat the survey in order to be able to evaluate the Park's management policies and measures together with the dynamic changes in the region.

During the longitudinal research concerning local inhabitants, the group of authors developed a standard methodology for evaluation and interpretation of the data. The main objective of the research was to examine and compare the attitudes of the local inhabitants to various environmental, management and tourism issues over a ten-year period.

The surveyed population included local residents over 15 years of age. The sample consisted of residents from six villages within the central-western part of the Sumava National Park (Kvilda, Horska Kvilda, Modrava, Srni, Prasily and Borova Lada) - see Figure 1. The population of all six villages was around 1000 [38]. The surveys were conducted during two nine-day periods in August 1998 and 2008.

Investigations were carried out by means of a questionnaire survey, administered through personal interviews in randomly selected households. Every second to fifth household was approached, according to the size of the village, and if the person answering the door met the conditions of the survey, he or she was interviewed. In both 1998 and 2008, identical questionnaires containing around 30 queries were used, having been modified on some topical issues only.

Firstly, descriptive statistics were derived in order to summarize the main results. Variations in responses among different opinion groups and between the two surveys were investigated by cross-tabulation and by performing a chi-squared $\left(\chi^{2}\right)$ test of independence. The level of significance was $95 \%$. 
In order to be able to further interpret the data, cluster analysis of the results from 1998 and 2008 was performed to identify relationships between residents' attitudes, demographic and other variables. The analysis was carried out on three of the questions using squared Euclidean distances with the average linkages agglomeration method. The three questions related to local evaluation of: (a) the National Park; (b) the state of the environment; and (c) the National Park Administration. These questions were selected according to primary statistical analysis and experience in the field. Study of the resulting dendrograms indicated the four-cluster solution to be the most useful for interpretation of the data. Clusters were further analyzed by examining the variation in demographic variables, management preferences and other socio-economic items.

\section{Results}

The total samples consisted of 181 questionnaires for 1998 and 200 for 2008. Only permanent residents completed the questionnaires. Weekenders, long-term visitors and seasonal workers were excluded from this study. The response rate was $75 \%$ in 1998 and $85 \%$ in 2008 . The share of respondents from each village was as follows: Srni $(14.4 \%$; 1998, 23.5\%; 2008), Borova Lada (25.4\%, 16.0\%), Kvilda (4.4\%, 22.0\%), Prasily (29.3\%, 16.0\%), Modrava (8.8\%, 12.0\%), Horska Kvilda (17.7\%, 10.5\%).

The first thematic block in the questionnaire deals with socio-demographic characteristics of the respondents. Table 1 shows the population characteristics of the two surveys in detail. In 1998, the largest group of respondents was the 40-59 age group. In 2008, the largest group was the 25-39 year group (X-square $=6.6931, \mathrm{df}=3, p$ value $=0.0824$ ). The ratio of men to women was essentially unchanged in both surveys. When comparing various occupations, the percentage of manual workers had decreased and the number of non-manual workers and entrepreneurs or investors had increased over the ten-year period $(\mathrm{X}$-square $=14.1023$, df $=5, p$ value $=0.015)$. Another change in the demographic structure was indicated by the higher percentage of respondents with a university degree in 2008 (X-square $=11.774, \mathrm{df}=4, p$ value $=0.0191)$. The potential effect of changes in respondents' demographic characteristics on their acceptance of the NP will be mentioned in the Discussion.

Residents' place relationship is considered by many authors to be an important indicator for the acceptance of NPs. In both of the surveys, only every fourth respondent was born in this region, the largest proportion of long-established settlers being found in Horska Kvilda, where approximately every third interviewee had some ancestors in this region: parents, grandparents or others. In the first survey, the 1980 's $(30.0 \%, \mathrm{~N}=127)$ had been the period of the most intensive immigration into the Sumava region whereas, in the 2008 study, the period of the most intensive immigration was 1995-2005 (32.1\%, $\mathrm{N}=112)$, followed by the 1980's (27.7\%). This means that the last few years have seen some significant changes in the region's residential structure. The most frequently mentioned reasons for moving to the Sumava region were: (a) a desire to live in a natural environment - expressed more frequently in the later study (1998; 9.5\%, 2008; 20.4\%); (b) new job opportunities; and (c) marriage or family ties. A large majority of the respondents felt at home in Sumava, although around $20 \%$ of them would be willing to leave the region if there was a better opportunity (mainly job opportunities $)$ elsewhere $(\mathrm{X}$-square $=13.3881, \mathrm{df}=5, p$ value $=0.02)$. 
Table 1. Socio-demographic characteristics of respondents.

\begin{tabular}{lcc}
\hline \multicolumn{1}{c}{ Age group } & $\mathbf{1 9 9 8}(\mathbf{\%})$ & $\mathbf{2 0 0 8}(\boldsymbol{\%})$ \\
\hline $15-24$ & 13.3 & 12.5 \\
$25-39$ & 30.9 & 35.0 \\
$40-59$ & 44.2 & 33.5 \\
$>60$ & 11.6 & 19.0 \\
\hline \multicolumn{1}{c}{ Gender } & & \\
\hline Male & 47.5 & 47.5 \\
Female & 52.5 & 52.5 \\
\hline$\quad$ Education & & \\
\hline Elementary and Middle School & 16.9 & 13.5 \\
Educational establishment & 32.6 & 24.0 \\
High School & 37.6 & 37.5 \\
Community college & 5.6 & 7.0 \\
University & 7.3 & 18.0 \\
\hline$\quad$ Employment & & 45.2 \\
\hline Public sector & 52.9 & 54.8 \\
Private sector & 47.1 & \\
\hline$\quad$ Occupational groups & & 9.0 \\
\hline Student & 4.0 & 24.0 \\
Manual worker & 30.9 & 24.0 \\
Non-manual worker & 18.3 & 16.0 \\
Entrepreneur & 14.9 & 22.0 \\
Retired & 18.9 & 5.0 \\
Unemployed or housewife & 13.1 & \\
\hline
\end{tabular}

\subsection{The Environment and Nature Conservation}

In the first question of this thematic block, respondents were asked to evaluate the existence of the Sumava National Park, see Table 2. When comparing the two surveys, statistically significant changes in local attitudes toward the NP was identified ( $\mathrm{X}$-square $=10.5382, \mathrm{df}=4, p$ value $=0.0323$ ). It is possible to observe an increase in the number of residents with both positive and negative attitudes to the existence of NP at the expense of residents with indefinite attitude.

The responses to a question concerning the respondents' evaluation of environmental conditions in the Sumava NP revealed some important differences between the two surveys (X-square $=12.7376$, $\mathrm{df}=3, p$ value $=0.0052)$. As we can see (Table 2), the distribution of answers has changed over the ten-year period towards a more positive evaluation of the natural environment. In the next query, respondents indicated whether they perceived the nature conservation scheme to be strict or moderate $(\mathrm{X}$-square $=22.4772, \mathrm{df}=5, p$ value $=0.0004)$, see Table 2 . When asked for additional comments, some respondents recommended more effective enforcement of certain laws, some complained about unnecessary restrictions and about a lack of transparency in building codes and the issuing of permits to build new facilities or houses in the area. The most frequently mentioned environmental problems in both surveys were the spruce bark beetle (Ips typhographus), the condition of the forests, intensive logging and mass tourism. 
Table 2. Respondents' evaluation of various aspects of the Sumava National Park.

\begin{tabular}{lcc}
\hline & $\mathbf{1 9 9 8}(\mathbf{\%})$ & $\mathbf{2 0 0 8}(\mathbf{\%})$ \\
\hline Your evaluation of the Sumava NP & \\
\hline Positive & 22.3 & 27.1 \\
Rather positive & 33.5 & 35.3 \\
Rather negative & 20.7 & 18.8 \\
Negative & 7.3 & 12.4 \\
Do not know & 16.2 & 6.5 \\
\hline State of the environment in the NP in the last ten years has & \\
\hline Improved & 47.5 & 52.4 \\
Not changed & 15.1 & 25.3 \\
Deteriorated & 27.9 & 18.8 \\
Do not know & 9.5 & 3.5 \\
\hline In your opinion, current nature protection regime in this NP is & \\
\hline Too strict & 4.7 & 16.0 \\
Rather strict & 12.3 & 20.9 \\
Optimal & 36.3 & 33.1 \\
Rather moderate & 23.4 & 19.0 \\
Too moderate & 13.5 & 6.1 \\
Do not know & 9.9 & 4.9 \\
\hline Evaluation of the National Park Administration office & \\
\hline Satisfied & 8.7 & 11.1 \\
Rather satisfied & 18.0 & 25.6 \\
Rather dissatisfied & 27.9 & 14.6 \\
Dissatisfied & 23.8 & 19.1 \\
Do not know & 21.5 & 29.6 \\
\hline Do you know about the grant programs available for local communities in PAs? & 27.6 & 12.0 \\
\hline Yes & 72.4 & 28.0 \\
No & & \\
Influence of the NP on job opportunities & 11.8 & \\
Increase & 14.0 & \\
No influence & 66.3 & \\
Decrease & 7.9 & \\
Do not know & & \\
\hline & & \\
\hline
\end{tabular}

In order to identify local problems, respondents were asked to choose, from a list, one problem deserving the greatest attention and one problem deserving the least attention. In 2008, the most crucial problems were as follows: (a) the condition of the forests $(32.2 \%)$; (b) the development of the infrastructure (20.1\%); and (c) mass recreational use (15.6\%). The problems deserving the least attention were: (a) water quality (37.0\%); (b) air quality $(27.7 \%)$; and (c) public transport (10.4\%). In 1998 the most crucial problems were very similar: (a) the condition of the forests $(31.5 \%)$; (b) the development of the infrastructure (28.9\%); and (c) mass recreational use (16.8\%).

The majority of respondents identified motoring (1998; 67.1\%, 2008; 50.3\%) as the recreational activity with the most negative impact on nature in the NP. In 2008, almost every fifth respondent saw cycling as having the second most negative impact. 
Although nature conservation is the main aim of the national parks in the Czech Republic, there are growing pressures from developers and entrepreneurs alike to open a new border crossing in the Sumava NP. This relates to a passionate discussion as to whether or not to open the new Modry Sloup/Blaue Saulen border crossing for hikers and cyclists in one of the most pristine areas of the NP. When respondents were asked about the new border crossing, $42.8 \%$ in 1998 and only $27.8 \%$ in 2008 felt that it could have a negative impact on the natural environment of the NP. The highest percentage of defenders of the new border crossing was found in Kvilda, possibly due to their positive experiences with a neighboring border crossing in Bucina.

When evaluating the administrative and management activities of the National Park Administration, every second interviewee in 1998 (51.7\%) was dissatisfied. In 2008, we used a more specific set of questions to evaluate three different areas of the NP Administration's activities. The National Park Administration was most positively assessed as an educational institution (70.0\%), then as an organization managing natural resources (48.5\%) and least positively as an administration office (35.5\%). Surprisingly, the largest group of respondents (34.5\%) held very negative attitudes towards the Administration as an institution managing natural resources. This was probably due to public controversy about logging and management of the Ips typographus calamity in the local forests. If we compare the results from the surveys - the evaluation of the NP Administration itself (1998) and its evaluation as an administration office (2008) — there is a significant improvement in local people's assessment over the ten-year period $(\mathrm{X}$-square $=14.1563 \mathrm{df}=4, p$ value $=0.0068)$, see Table 2 . In the next question, we found a steep increase within these ten years in respondents' knowledge of grant programs available for local communities in protected areas $(\mathrm{X}$-square $=26.1562$, $\mathrm{df}=1$, $p$ value $=0$ ), see Table 2 .

\subsection{Local Development and Tourism in the NP}

The third thematic block started with a question examining the availability of job opportunities in the region. This availability was assessed as 'very insufficient' by $68.5 \%$ in $1998(58.0 \%$ in 2008$)$ and as 'insufficient' by $18.0 \%$ in 1998 (24.5\% in 2008). In the next item, respondents were asked whether the designation of the area as a NP has affected job opportunities. In 1998, 66.3\% of respondents claimed that the designation had led to a decrease in job opportunities, but this number dropped to $41.5 \%$ in 2008 (see Table 2). The percentage of respondents suggesting that the designation of the NP actually created new job opportunities increased from $11.8 \%$ in 1998 to $18.5 \%$ in 2008 $(\mathrm{X}$-square $=23.8043, \mathrm{df}=3, p$ value $=0)$.

To determine the extent of local involvement in the tourism industry, respondents were questioned as to whether or not they had made any profit from tourism. Seven years after the designation of the Sumava NP, $22.1 \%$ of the respondents had made an economic profit from the tourism industry. Seventeen years after the designation, that number had risen to $30.0 \%$. Many respondents $38.7 \%$ in $1998,86.9 \%$ in 2008) recognized nature and natural resources as the most attractive feature of the area. According to the respondents, there has been a continuous increase in the number of visitors since the early 1990's.

As a follow-up to the previous question, locals were asked how they perceived the 'intensity' of tourism in the NP. The aim of this question was to determine the social carrying capacity of the 
destination from a local point of view. Results showed that the respondents $(74.6 \%$ in 1998 and $73.3 \%$ in 2008) were not concerned about visitor levels on the hiking trails. Similar responses $(64.7 \%$ in 1998 and $71.0 \%$ in 2008) were identified regarding visitor levels in the proximity of the respondent's place of residence. Looking at the negative responses, locals seemed to be more concerned about visitor levels in the proximity of their places of residence than those on the hiking trails. When asked to identify the most disturbing aspects of Park tourism, respondents most frequently stated: (a) undisciplined and unrestrained visitors (32.6\% in 1998, 37.5\% in 2008); (b) litter (21.7\% in 1998, $30.5 \%$ in 2008); and (c) motoring (11.4\% in 1998 and $18.0 \%$ in 2008).

\subsection{Cluster Analysis}

The main aim of the cluster analysis was to assign respondents to similar opinion groups and to test dependencies on variables. From the resulting dendrograms, the four-cluster solution appeared to be the most useful in interpreting the data in both surveys. These clusters were created on the basis of the responses that deal with evaluations of: the existence of the NP, the state of the environment, and the activity of NP Administration. These groups represented 23.7\%, 25.0\%, 15.4\%, 35.9\% (N = 156) of the 1998 sample and $37.9 \%, 26.1 \%, 17.4 \%, 18.6 \%(\mathrm{~N}=161)$ of respondents in 2008 (Figure 2), for details see Table 3. All differences mentioned in the following text were statistically significant $(p<0.05)$.

Figure 2. Clusters changes between 1998 and 2008.

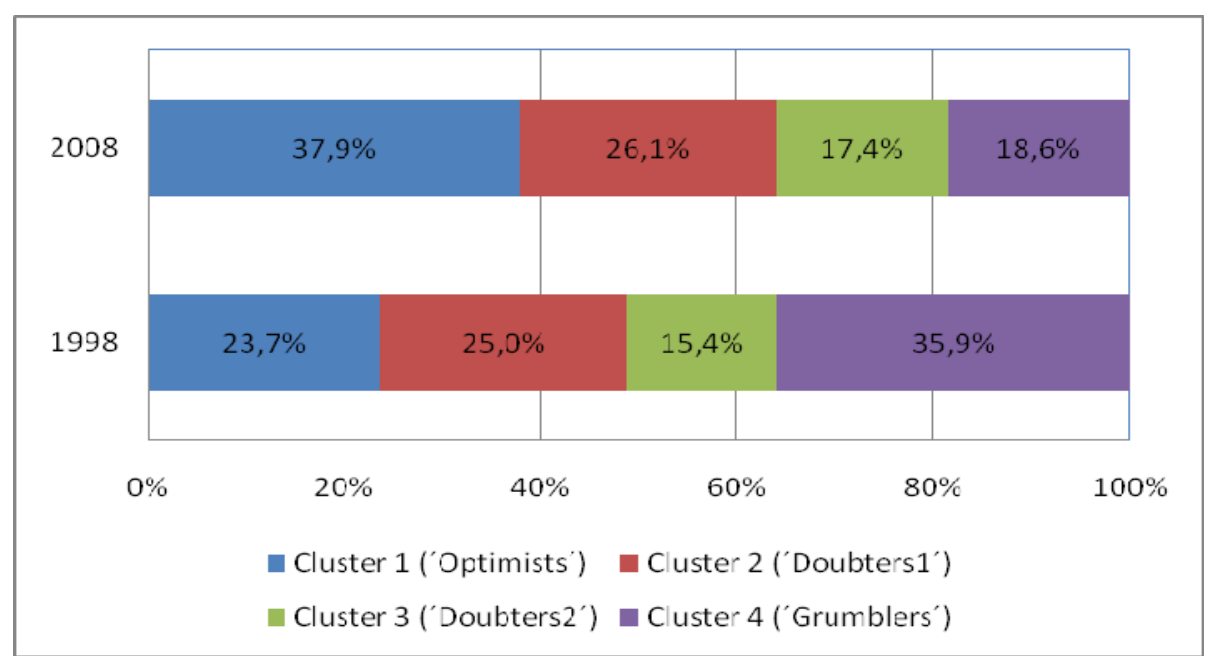

The cluster analysis showed very important changes in local acceptance of the Sumava National Park over the study period (1998-2008). Respondents in the two extreme clusters (No. 1 'Optimists' and No. 4 'Grumblers') had similar characteristics in both surveys and there was a significant change in the number of respondents placed into each of these two clusters. The number of 'Optimists' increased from $23.7 \%$ to $37.9 \%$ and the number of 'Grumblers' decreased from $35.9 \%$ to $18.6 \%$ (see Figure 2). Respondents in the remaining two clusters (No. 2 and 3) were called 'Doubters' as they held rather skeptical opinions on some of the main issues. The total portion of 'Doubters' remained almost the same (40.4\% in 1998 and 43.5\% in 2008). Cluster No. 2 called 'Doubters 1' represents residents with negative attitudes towards the National Park and neutral attitudes to the NP Administration 
activities. These respondents also saw the state of the environment as unchanged or worsened. 'Doubters 2' (cluster No. 3) were residents with very negative attitudes towards the National Park and the NP Administration but they perceived the state of the environment as improved.

Table 3. Cluster analysis.

\begin{tabular}{|c|c|c|c|c|c|}
\hline \multicolumn{6}{|l|}{1998} \\
\hline \multicolumn{6}{|c|}{ Your evaluation of the Sumava NP... } \\
\hline & $\begin{array}{c}\text { Cluster } 1 \\
\text { ('Optimists') }\end{array}$ & $\begin{array}{c}\text { Cluster } 2 \\
\text { ('Doubters1') }\end{array}$ & $\begin{array}{c}\text { Cluster } 3 \\
\text { ('Doubters2') }\end{array}$ & $\begin{array}{c}\text { Cluster } 4 \\
\text { ('Grumblers') }\end{array}$ & Total \\
\hline & $\%(n=37)$ & $\%(n=39)$ & $\%(n=24)$ & $\%(n=56)$ & $\%(n=156)$ \\
\hline Positive & 70.3 & 20.5 & 0.0 & 0.0 & 21.8 \\
\hline Rather positive & 27.0 & 51.3 & 0.0 & 0.0 & 19.2 \\
\hline Do not know & 2.7 & 28.2 & 0.0 & 0.0 & 7.7 \\
\hline Rather negative & 0.0 & 0.0 & 50.0 & 37.5 & 21.2 \\
\hline Negative & 0.0 & 0.0 & 50.0 & 62.5 & 30.1 \\
\hline \multicolumn{6}{|c|}{ State of the environment in the NP in the last ten years has... } \\
\hline Improved & 37.8 & 20.5 & 16.7 & 7.1 & 19.2 \\
\hline Not changed & 29.7 & 46.2 & 8.3 & 30.4 & 30.8 \\
\hline Deteriorated & 32.4 & 33.3 & 75.0 & 62.5 & 50.0 \\
\hline \multicolumn{6}{|c|}{ With the NP Administration you are... } \\
\hline Satisfied & 29.7 & 0.0 & 12.5 & 0.0 & 9.0 \\
\hline Rather satisfied & 43.2 & 0.0 & 37.5 & 0.0 & 16.0 \\
\hline Do not know & 27.0 & 23.1 & 50.0 & 0.0 & 19.9 \\
\hline Rather dissatisfied & 0.0 & 59.0 & 0.0 & 39.3 & 28.8 \\
\hline Dissatisfied & 0.0 & 17.9 & 0.0 & 60.7 & 26.3 \\
\hline \multicolumn{6}{|l|}{2008} \\
\hline \multicolumn{6}{|c|}{ Your evaluation of the Sumava NP... } \\
\hline & $\begin{array}{c}\text { Cluster } 1 \\
\text { ('Optimists') }\end{array}$ & $\begin{array}{c}\text { Cluster } 2 \\
\text { ('Doubters 1') }\end{array}$ & $\begin{array}{c}\text { Cluster } 3 \\
\text { ('Doubters2') }\end{array}$ & $\begin{array}{c}\text { Cluster } 4 \\
\text { ('Grumblers') }\end{array}$ & Total \\
\hline & $\%(n=61)$ & $\%(n=42)$ & $\%(\mathrm{n}=28)$ & $\%(n=30)$ & $\%(n=161)$ \\
\hline Positive & 42.6 & 0.0 & 28.6 & 0.0 & 21.1 \\
\hline Rather positive & 52.5 & 0.0 & 71.4 & 0.0 & 32.3 \\
\hline Do not know & 4.9 & 21.4 & 0.0 & 0.0 & 7.5 \\
\hline Rather negative & 0.0 & 45.2 & 0.0 & 56.7 & 22.4 \\
\hline Negative & 0.0 & 33.3 & 0.0 & 43.3 & 16.8 \\
\hline \multicolumn{6}{|c|}{ State of the environment in the NP has... } \\
\hline Improved & 50.8 & 16.7 & 60.7 & 10.0 & 36.0 \\
\hline Not changed & 24.6 & 42.9 & 17.9 & 30.0 & 29.2 \\
\hline Deteriorated & 13.1 & 26.2 & 14.3 & 56.7 & 24.8 \\
\hline Do not know & 11.5 & 14.3 & 7.1 & 3.3 & 9.9 \\
\hline \multicolumn{6}{|c|}{ With the NP Administration you are... } \\
\hline Satisfied & 16.4 & 23.8 & 0.0 & 0.0 & 12.4 \\
\hline Rather satisfied & 52.5 & 26.2 & 0.0 & 0.0 & 26.7 \\
\hline Do not know & 31.1 & 50.0 & 0.0 & 0.0 & 24.8 \\
\hline Rather dissatisfied & 0.0 & 0.0 & 42.9 & 43.3 & 15.5 \\
\hline Dissatisfied & 0.0 & 0.0 & 57.1 & 56.7 & 20.5 \\
\hline
\end{tabular}


In 1998 , the most positive cluster $(\mathrm{N}=37)$ consisted of respondents holding very positive attitudes towards the Sumava NP, being satisfied with the NP Administration and most often perceiving the state of the environment as improved. The majority of respondents from this cluster were employed in the public sector, perceived the scheme for nature conservation in the NP to be optimal or moderate and assessed job opportunities in the Sumava region more positively compared to the other clusters. There were no entrepreneurs in this cluster. In 2008 the cluster with the most positive reactions consisted of 61 respondents. These respondents similarly perceived the NP positively, were satisfied with the NP Administration as an administration office and saw the state of the environment as improved or unchanged. Most respondents from this cluster evaluated the nature conservation scheme as optimal or moderate and believed that the establishment of the Sumava NP had had a positive effect on job opportunities in the region. These respondents' perceptions agreed almost entirely with the aforementioned cluster of 1998.

When we focus on the most negative clusters, the 1998 cluster $(\mathrm{N}=56)$ comprised respondents holding very negative attitudes towards the National Park and the NP Administration. In their opinion, the state of the environment had worsened. Most of these respondents were employed in the private sector, assessed the nature conservation scheme as either too strict or too moderate, and job opportunities as highly insufficient. This cluster also contained the highest number of entrepreneurs. In 2008, the most negative cluster $(\mathrm{N}=30)$ consisted of respondents perceiving the NP negatively, being dissatisfied with the NP Administration and evaluating the environment as having worsened. They believed that the establishment of the National Park had limited job opportunities and they assessed the nature conservation scheme as too strict.

\section{Discussion and Conclusions}

Sumava is a very dynamic and specific region where local people do not have a longstanding (in the context of living for several generations) relationship to the area. Therefore, we expected very negative attitudes toward the NP. However, the results of the study did not confirm our presumption and the research indicated significant changes in respondents' characteristics and consequently in their attitudes and perceptions within the 10-year period. Some of the positive changes in local people's acceptance of the NP could have been influenced by changes in the demographic structure of the population and some could have been influenced by changes in the management of the NP. In many cases, we did not succeed in identifying which influence was the strongest. This is certainly a challenge for our future research.

Respondents from the later survey could be characterized as being more highly-educated non-manual workers, less economically dependent on traditional activities, such as logging and, thus, holding more environmentally-friendly attitudes. During the last 15 years, many new residents have settled in the area, often coming from neighboring districts and from the capital city of the Czech Republic. These results support Krannich's [39] suggestion that, despite the fact that there are lower wages and higher unemployment in a wilderness area, more young, well-educated and welltrained people are willing to accept lower incomes in return for a higher quality of life. Sustainable economic growth and development of the Sumava region lies not with the exploitation of natural 
resources, but rather in the utilization of the natural environment as a place. The principal driving force in this new economy is environmental quality.

An illustration of these profound shifts in the composition of the residents is the considerable change in the quantity of successful interviews in selected villages (the refusal rate $25 \%$ in 1998 and $15 \%$ in 2008), despite the fact that the same method of random selection of the households was used in both surveys. Apart from the population changes, the number of refusals was higher in 1998, particularly in certain villages, and this could have influenced the results. As mentioned in previous chapters, many local inhabitants of Sumava do not have a long-standing relationship (multigenerational) with the region. If we define the place attachment (place relationship) as the 'effective link that people establish with specific settings, where they tend to remain and where they feel comfortable and safe' [36], the newcomers presented high place relationship and appreciation of the natural environment, in contrast to long-established settlers. The newcomers also declared stronger support for conservation policies. These findings conform to other works showing a positive correlation between place relationship and conservation policies [24]. In our research, it is important to emphasize that proclaimed strong ties to the region do not correspond only with a long-term relationship to the region. Longer-established settlers previously employed in the logging industry were very negative about the NP, probably due to the restriction in logging and the subsequent loss of jobs. In agreement with other studies [25], entrepreneurs' attitudes toward the NP and connected issues were rather negative. This relates to the basic conflict between the development of tourism, supported by its stakeholders, and the limits on tourism imposed by the NP management.

There has been a significant improvement in local people's attitude towards the existence of the NP. Besides the changes in population characteristics mentioned in the previous paragraph, other important factors are involved. Firstly, there was a new management plan introduced in 2001, recommended by the IUCN mission, which included a new approach toward local inhabitants and their involvement in the management process [40]. Since then, many public meetings and discussions about various local issues have taken place, and communication between the NP Administration and local authorities has significantly improved. In addition, public knowledge about grant programs and environmental problems has also greatly improved. The second factor involved could be the development of a huge disagreement, which arose between the public and the Park Administration over how to deal with the vast destruction of the forests (mostly non-native spruce monocultures) caused by remote industrial emissions and infestation by the spruce bark beetle (Ips typographus).

The most crucial local problems perceived by respondents were: (a) the condition of the forests; (b) the development of the infrastructure; and (c) mass recreational use. Therefore, environmental and tourism issues were mainly involved. To place our findings in the context of other studies, we may consider that of Trakolis [10,21], who surveyed local populations of two Greek national parks. In his studies, respondents chose the following list of works and facilities: provision of recreation facilities; forest roads; reforestation; watering-troughs; information centers and landscape architecture works. Some authors [41-44] have concluded that inhabitants of heavily tourism-developed regions have better knowledge of the negative impacts of recreational use, but at the same time they prefer further development of tourism infrastructure. Similarly, our findings show that respondents are aware of the environmental problems caused by massive tourism development, but at the same time, they support the opening of a new border crossing in the central part of the NP. This issue is a very important one as 
it generates negative attitudes toward the NP, mainly among the entrepreneurs and those respondents involved in tourism. It is necessary to increase public awareness, as the planned border crossing is situated in an area with Tetrao urogallus, also known as the Wood Grouse or more specifically the Western Capercaillie, which is an endangered species, and this is one of the few vital populations in the Czech Republic. In spite of the increasing number of visitors and the involvement of local inhabitants, the tourism infrastructure in Sumava NP remains relatively undeveloped. So, at this point it is very important that the National Park management, local authorities and Park inhabitants work together to develop a sustainable program that will build a tourism infrastructure while protecting the local environment [28].

In 2008, cycling was seen by almost every fifth respondent as having the second most negative impact. This is mainly because, in the last few years, there has been a significant increase in the number of cyclists and cyclist-related conflicts between hikers and bikers on the common trails [45] and as a result, more local respondents considered cycling an undesirable recreational activity. This finding indicates a recommendation to consider some limits on cyclists by the NP management.

Most respondents were not concerned about the number of visitors in the NP. According to other studies [46,47], close community ties and place attachment lead to a greater sensitivity to the social and cultural impacts of tourism. In our surveys, however, we did not identify any statistically significant relationship between place relationship and perception of visitation levels.

This research was carried out in a period of important economic and geo-political changes. The Park management succeeded not only in handling the situation, but also in using it favorably throughout to improve the social climate amongst locals and also their acceptance of the NP. Economic development has been concentrated inside the region, not outside, so mainly local residents have been able to profit from tourism. All of this was achieved on a regional scale, and without massive development or commercialization of the area, which is currently the most crucial problem of protected areas in both developed and developing countries.

\section{Acknowledgments}

This project was financially supported by the Grant Agency of Charles University in Prague and by the Ministry of Environment of the Czech Republic. The authors also wish to thank other participants involved in the project, namely Mr. L. Silovsky for his help with organizing both surveys and Ms. Z. Tancosova and students of Charles University in Prague for their cooperation in collecting and analyzing our data. Special thanks belong to Mr. Richard Tanton and Mrs. Philippa King for the final proofreading.

\section{Conflict of Interest}

The authors declare no conflict of interest. 


\section{References}

1. Ceballos-Lascuráin, H. Tourism, Ecotourism and Protected Areas: The State of Nature based Tourism around the World and Guidelines for Its Development; IUCN: Gland, Switzerland, 1996.

2. Nepal, S.K. Involving indigenous peoples in protected area management: Comparative perspectives from Nepal, Thailand, and China. Environ. Manag. 2002, 30, 748-763.

3. Baldus, R.D.; Siege, L.; Kibonde, B. Seeking conservation partnerships in the selous game reserve, Tanzania. Parks 2003, 13, 50-61.

4. Mbaiwa, J.; Stronza, A. The effects of tourism development on rural livelihoods in the Okavango Delta, Botswana. J. Sustain. Tour. 2010, 18, 635-656.

5. Gungor, B.S. Management system of protected areas for sustainable use of natural resources. J. Environ. Prot. Ecol. 2007, 8, 434-441.

6. Kideghesho, J.R.; Røskaft, E.; Kaltenborn, B.P. Factors influencing conservation attitudes of local people in Western Serengeti, Tanzania. Biodivers. Conserv. 2007, 16, 2213-2230.

7. Mannigel, E. Integrating parks and people: How does participation work in protected area management? Soc. Nat. Resour. 2008, 21, 498-511.

8. Gurung, D.B.; Seeland, K. Ecotourism in Bhutan: Extending its benefits to rural communities. Ann. Tour. Res. 2008, 35, 489-508.

9. Brooks, J.; Franzen, M.; Holmes, C.; Grote, M.; Borgerhoff, M. Testing hypotheses for the success of different conservation strategies. Conserv. Biol. 2006, 20, 1528-1538.

10. Trakolis, D. Perceptions, preferences, and reactions of local inhabitants in Vikos-Aoos National Park, Greece. Environ. Manag. 2001, 28, 665-676.

11. Fisher, B.; Treg, C. Poverty and biodiversity: Measuring the overlap of human poverty and the biodiversity hotspots. Ecol. Econ. 2007, 62, 93-101.

12. Rao, K.S.; Nautiyal, S.; Maikhuri, R.K.; Saxena, K.G. Local peoples' knowledge, attitude and perceptions of planning and management issues in Nanda Devi Biosphere Reserve, India. Environ. Manag. 2003, 31, 168-181.

13. Coria, J.; Calfucura, E. Ecotourism and the development of indigenous communities: The good, the bad and the ugly. Ecol. Econ. 2012, 73, 47-55.

14. Durrant, J.O.; Shumway, J.M. Attitudes toward wilderness study areas. A survey of six southeastern utah counties. Environ. Manag. 2004, 33, 271-283.

15. Lepp, A.; Holland, S. A comparison of attitudes toward state-led conservation and community-based conservation in the village of Bigodi, Uganda. Soc. Nat. Resour. 2006, 19, 609-623.

16. McCleave, J.; Espiner, S.; Booth, K. The New Zealand people-park relationship: An exploratory model. Soc. Nat. Resour. 2006, 19, 547-561.

17. Allendorf, T.D.; Smith, J.L.D.; Anderson, D.H. Residents' perceptions of Royal Bardia National Park, Nepal. Landsc. Urban Plan. 2007, 82, 33-40.

18. Spiteri, A.; Nepal, S.K. Distributing conservation incentives in the buffer zone of Chitwan National Park, Nepal. Environ. Conserv. 2008, 35, 76-86. 
19. Kusova, D.; Tesitel, J.; Matejka, K.; Bartos, M. Biosphere reserves-An attempt to form sustainable landscapes. A case study of three biosphere reserves in the Czech Republic. Landsc. Urban Plan. 2008, 84, 38-51.

20. Frauman, E.; Banks, S. Gateway community resident perceptions of tourism development: Incorporating importance-performance analysis into the limits of change framework. Tour. Manag. 2011, 13, 128-140.

21. Trakolis, D. Local people's perceptions of planning and management issues in Prespes Lakes National Park, Greece. J. Environ. Manag. 2001, 61, 227-241.

22. Walpole, M.; Goodwin, H. Local attitudes towards conservation and tourism around Komodo National Park, Indonesia. Environ. Conserv. 2001, 28, 160-166.

23. Deery, M.; Jago, L.; Fredline, L. Rethinking social impacts of tourism research: A new research agenda. Tour. Manag. 2012, 33, 64-73.

24. Walkera, A.J.; Ryan, R.L. Place attachment and landscape preservation in rural New England: A Maine case study. Landsc. Urban Plan. 2008, 86, 141-152.

25. Bonaiuto, M.; Carrus, G.; Martorella, H.; Bonnes, M. Local identity processes and environmental attitudes in land use changes: The case of natural protected areas. J. Econ. Psychol. 2002, 23, 631-653.

26. Brooks, J.; Franzen, M.; Holmes, C.; Grote, M.; Borgerhoff, M. Testing hypotheses for the success of different conservation strategies. Conserv. Biol. 2006, 20, 1528-1538.

27. Torquebiau, E.; Taylor, R. Natural resource management by rural citizens in developing countries: Innovations still required. Biodivers. Conserv. 2009, 18, 2537-2550.

28. Cihar, M.; Tancosova, Z.; Trebicky, V. Sumava National Park and selected aspects of its sustainable development_Evaluation by the local people (communities of Borova Lada, Horska Kvilda, Kvilda, Modrava, Filipova Hut, Srni a Prasily). Silva Gabreta 2000, 5, 195-216.

29. Cihar, M.; Stursa, J.; Trebicky, V. Monitoring of tourism in the Czech National Parks. In Proceedings of the Monitoring and Management of Visitor Flows in Recreational and Protected Areas, Vienna, Austria, 30 January-2 February 2002; Arnberger, A., Brandenburg, C., Muhar, A., Eds.; Bodenkultur University: Vienna, Austria, 2002; pp. 240-245.

30. Cihar, M.; Stankova, J. Attitudes of stakeholders towards the Podyji/Thaya River Basin National Park in the Czech Republic. J. Environ. Manag. 2006, 81, 273-285.

31. Gorner, T.; Cihar, M. Seasonal differences in visitor perceptions: A comparative study of three mountainous national parks in central Europe. J. Environ. Prot. 2011, 2, 1046-1054.

32. International Union for Conservation of Nature. The Mountains of Central and Eastern Europe; IUCN: Gland, Switzerland, 1995.

33. Ulbrichova, J.; Remes, J.; Zahradnik, D. Development of the spruce natural regeneration on mountain sites in the Šumava Mts. J. For. Sci. 2006, 52, 446-456.

34. Kluvankova-Oravska, T.; Chobotova, V.; Banaszak, I.; Slavikova, L.; Trifunovova, S. From government to governance for biodiversity: The perspective of Central and Eastern European transition countries. Environ. Policy Gov. 2009, 19, 186-196.

35. Kusova, D.; Bartos, M.; Tesitel, J. Potential development of the right shore of Lipno Lake area: Comparison of landscape and urban planning documentation with ideas of local inhabitants. Silva Gabreta 1999, 3, 217-228. 
36. Petrova, S.; Cihar, M.; Bouzarovski, S. Local nuances in the perception of nature protection and place attachment: A tale of two parks. Area 2011, 43, 327-335.

37. Furlong, K. Unexpected narratives in conservation: Discourses of identity and place in Sumava National Park, Czech Republic. Space Polity 2006, 10, 47-65.

38. Czech Statistical Office. Statistical Yearbook of the Czech Republic 2008, 1st ed.; CZSO: Prague, Czech Republic, 2008.

39. Krannich, R.; Luloff, A.E.; Field, D.R. People, Places and Landscapes. Social Change in High Amenity Rural Areas, 1st ed.; Springer: Berlin, Germany, 2011.

40. Ministry of the Environment. Management of the Sumava National Park: IUCN Mission; MoE: Prague, Czech Republic, 2003.

41. Andriotis, K.; Vaughan D.R. Urban residents' attitudes towards tourism development: The case of Crete. J. Travel Res. 2003, 42, 172-185.

42. Haralambopoulos, N.; Pizam, A. Perceived impacts of tourism: The case of Samos. Ann. Tour. Res. 1996, 23, 503-526.

43. King, B.; Pizam, A.; Milman, A. Social impacts of tourism: Host perception. Ann. Tour. Res. 1993, 20, 650-665.

44. Vargas-Sánchez, A.; Porras-Bueno, N.; Plaza-Mejía, M. Explaining residents' attitudes to tourism. Is a universal model possible? Ann. Tour. Res. 2011, 38, 460-480.

45. Trebicky, V.; Cihar, M. Analysis of Nature-based Tourism in the Sumava National Park, Czech Republic: 1997-2004. In Proceedings of the 3rd International Conference on Monitoring and Management of Visitor Flows in Recreational and Protected Areas, Rapperswil, Switzerland, 13-17 September 2006; Siegrist, D., Clivaz, D., Hunziker, M., Iten, S., Eds.; Research Centre for Leisure, Tourism and Landscape, Institute for Landscape and Open Space: Rapperswil, Switzerland; pp. 228-232.

46. Payton, M.A.; Fulton, D.C.; Anderson, D.H. Influence of place attachment and trust on civic action: A study at Sherburne National Wildlife Refuge. Soc. Nat. Resour. 2005, 18, 511-528.

47. Williams, J.; Lawson, R. Community issues and resident options of tourism. Ann. Tour. Res. 2001, 28, 269-290.

(C) 2012 by the authors; licensee MDPI, Basel, Switzerland. This article is an open access article distributed under the terms and conditions of the Creative Commons Attribution license (http://creativecommons.org/licenses/by/3.0/). 